Jap. J. Limnol. 44, 3, 155-172, 1983.

\title{
Chemical Composition of Natural Waters and Rock Weathering in the Izu Peninsula Area as an Index to Earthquake-Caused Landslides
}

\author{
Yasushi Kitano, Seisuke NAKAmURA, Motoshi \\ TAKEMURA and Kiyotaka MAJIMA
}

\begin{abstract}
Natural waters in the Izu Peninsula area were analyzed in connection with earthquake predictions and ground stability in the area.

No relationship was observed between earthquakes and the chemical composition of natural waters. From the chemical composition of natural waters, the amount of rock forming minerals chemically weathered and also the amount of clay minerals formed were estimated. Chemical analyses of natural waters were found to be a valuable and useful index to ground stability in connection with earthquakerelated landslides.
\end{abstract}

\section{Introduction}

Recently many studies have been carried out to find a method to predict earthquakes. Some geochemists have reported that radon, helium, argon and hydrogen gases in ground waters are good indicators (WAKITA et al., 1980). Others have proposed that chemical analyses of anions in ground waters are useful for earthquake prediction (Yoshiok , 1978). Various kinds of monitoring are now being attempted for the prediction of earthquakes in the Izu Peninsula area of Japan, where earthquakes have been frequent since 1974 (see Table 1). The authors collected natural water samples three times in this peninsula area and analysed their major chemical constituents. No clear relationship between the chemical composition of natural water and the occurrence of earthquakes was established, but the analytical data on the natural waters may serve as a basis for future earthquake prediction studies in this area.

The present investigators consider that the chemical composition of natural water may be related to earthquake occurrence in the following two ways. First, an earthquake might be predictable on the basis of the anion concentration (volatile materials) in natural water. Some anions in natural water are supplied from subterranean parts of the area. And the concentrations of some anions may give some information on certain events occurring in subterranean parts of the area. A second point concerns the ground stability in connection with landslides, as determined mainly from the cation concentration in natural water. Water-rock interaction causes the dissolution of cations from rock forming minerals into natural water and the transformation from rock forming minerals into clay minerals. Thus, the chemical composition of natural water may indicate the extent of the chemical weathering of rocky materials, the formation of clay minerals and the ground stability (KiTANO and NAKAMURA, 1973; Kitano, $1980 \mathrm{a}$, b). One of the most serious disasters resulting from earthquakes is the damage from landslides. Therefore, it is important to have detailed and accurate information on ground stability. In this study, the chemical analysis of groundwater did not provide a means to predict earthquakes, but the analytical result of natural water indeed is an index to ground stability which is a key indicator for landslides triggered by earthquakes. 


\section{Experimental}

Collection of water samples: Natural water samples were collected three times for the chemical analysis of water quality at the various stations shown in Fig. 1, before and after the earthquakes shown in Table 1: Irozaki, Iruma and Nakagi in Nov. 1976; various stations throughout the peninsula in July 1977; and various stations in the Inatori area, where the Izu-Ohshima earthquake occurred, in March 1978. Chemical analyses: $\mathrm{pH}$, glass electrode $\mathrm{pH}$ meter; $\mathrm{HCO}_{3}^{-}$, titration with hydrochloride standard solution and bromcrezol purple indicator; $\mathrm{Cl}^{-}$, colorimetry with mercury thiocyanate; $\mathrm{SO}_{4}^{2-}$, colorimetry with thoriummorin complex (NASU, 1969); $\mathrm{Ca}^{2+}$ and $\mathrm{Mg}^{2+}$, atomic absorption spectrophotometry; $\mathrm{Na}^{+}$and $\mathrm{K}^{+}$, flame emission spectrophotometry; and soluble $\mathrm{SiO}_{2}$, colorimetry with ammonium molybdate.

\section{Results and Discussion}

As pointed out earlier, the analytical results in natural waters seem very important and useful for future studies on earthquake prediction in this area. These analytical results are presented in Tables $\mathrm{A}, \mathrm{B}$ and $\mathrm{C}$ as an Appendix.

(A) Relationship between earthquakes and chemical composition of natural water.

Anions are volatile materials, and some anions in natural water originate in deep parts of the earth. However, some $\mathrm{Cl}^{-}$ions come from sea water, some $\mathrm{SO}_{4}^{2-}$ ions through the oxidation of iron sulfide, and some $\mathrm{HCO}_{3}^{-}$ions from oxidation of organic material. Therefore, the concentrations of anions in natural water do not always indicate a geochemical change and events occurring in deep parts of the earth. Cations are supplied into natural water mostly through the chemical weathering processes of rocks. Therefore, the change in the anion concentration in natural water could be expected to have a more significant connection with earthquakes than that of cations. Western and southern Izu Peninsula areas are covered with Neogene rocks. The eastern part has Quaternary pyroclastic rocks. The authors examined the relationship between earthquakes and anion concentrations in natural water using data shown in Tables A, B and C (Appendix). However, no clear relationship could be foundbetween the occurrence of earthquakes and the change in anion concentrations in natural water. It was noted that natural waters in the southern part of Izu Peninsula (St. 27) and in the Inatori area (Sts. 74 and 92) exhibited very high concentrations of dissolved constituents. These waters flow out through a fault.

Table 2 shows the chemical compositions of two representative natural waters in the individual sampling area. The natural water at St. 27 in the Yumigahama area is very interesting (see Table 2), because

Table 1. Occurrence of earthquake and water sampling in the Izu Peninsula area.

\begin{tabular}{|c|c|c|c|}
\hline \multicolumn{2}{|r|}{ Occurrence of earthquake } & \multicolumn{2}{|c|}{ Sampling of waters for chemical analyses } \\
\hline Date & Name of earthquake (magnitude) & Date & Numbers of water sample \\
\hline May 9,1974 & Off-Izu Peninsula earthquake ( $M$ 6.9) & & \\
\hline Aug. 18, 1976 & Kawazu earthquake (M 5.4) & Nov., 1976 & 18 \\
\hline & & Jul., 1977 & 98 \\
\hline Jan. 4,1978 & Izu-Ohshima earthquake (M 7.4) & May, 1978 & 90 \\
\hline Dec. 3,1978 & Itoh-Kawanasaki earthquake (M 5.4) & & \\
\hline Jun. 29, 1980 & $\begin{array}{l}\text { Off-east part of Izu Peninsula } \\
\text { earthquake (M 6.7) }\end{array}$ & & \\
\hline
\end{tabular}




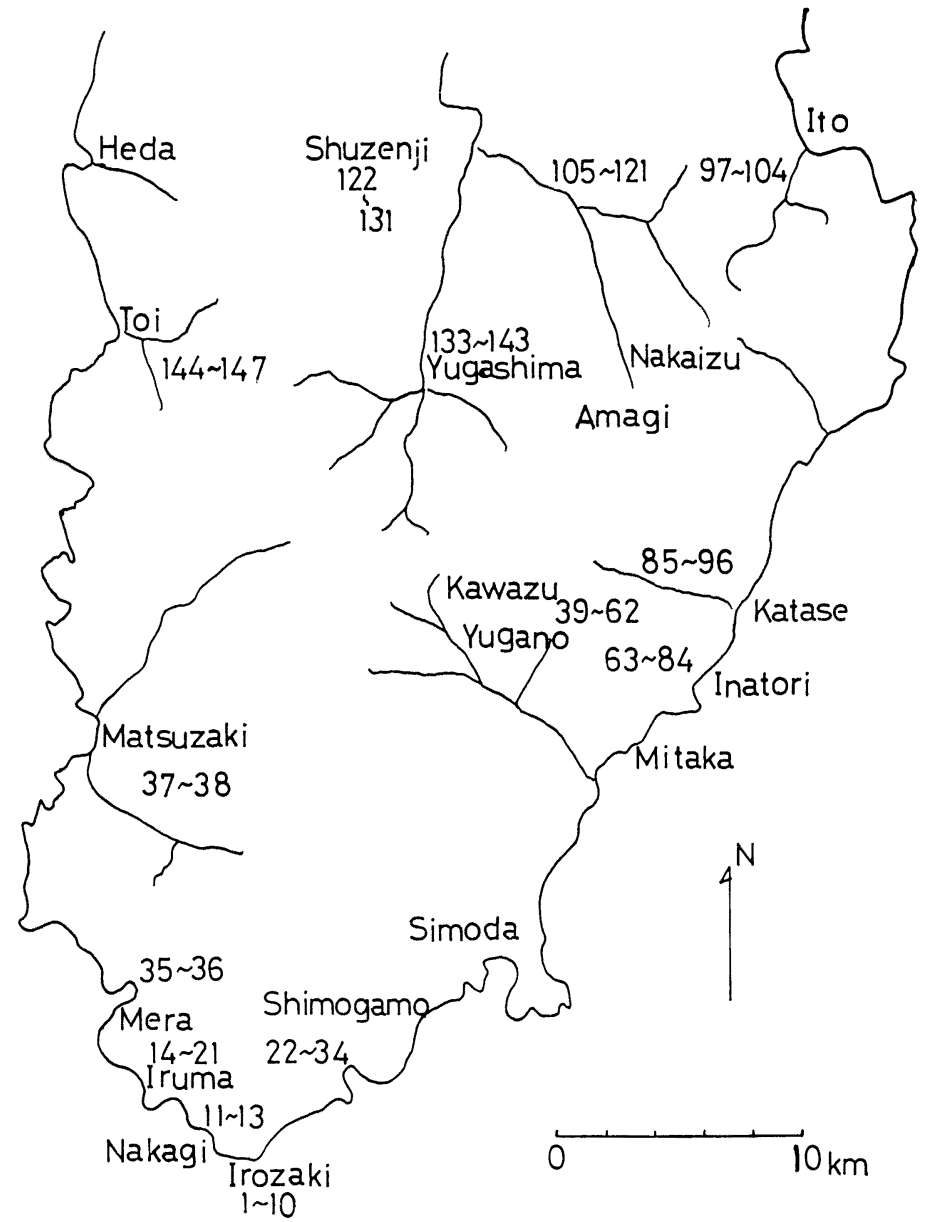

Fig. 1. Locations of natural water sampling in the Izu Peninsula area. (Figure in map denotes station number).

it is a calcium-chloride type water. This type of water has been found only at special stations such as Don Juan Pond in Antarctica, the deep seawater layer in the Red Sea, and the brine waters in oil fields. The major chemical constituents in these waters are calcium and chloride ions, and usually the high concentrations range from 300 to $400 \mathrm{~g} \cdot l^{-1}$. KITANO and his coworkers found this calcium-chloride type water in the ground water of the Matsushiro swarm earthquake area in Japan (KITANo et al., 1968; Yoshiok a et al., 1970). The authors discussed the processes involved in the formation of the calcium-chloride type water. A calcium-chloride type water was also found here in Izu Peninsula at St. 27. It should be noted that St. 27 is situated in a typical fault area.

The key diagram classification of natural waters from these chemical compositions is shown in Table 3, which indicates the types of natural waters.

(B) Estimation of the amounts of silicate minerals weathered, clay minerals formed, and calcium carbonate and silica dissolved.

In order to estimate the above-mentioned amounts from the chemical composition of natural water, the amounts of $\mathrm{Na}^{+}, \mathrm{K}^{+}$, $\mathrm{Ca}^{2+}$, and $\mathrm{Mg}^{2+}$, dissolved into natural water from rocky materials for one year, 


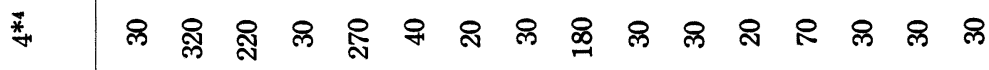

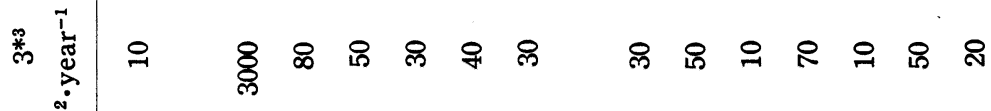

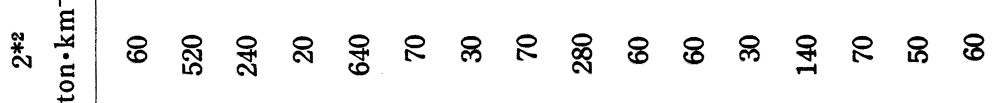

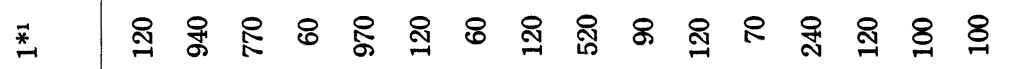
בํํㄹำ

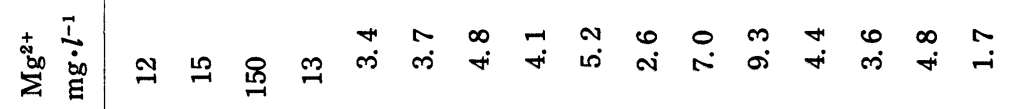

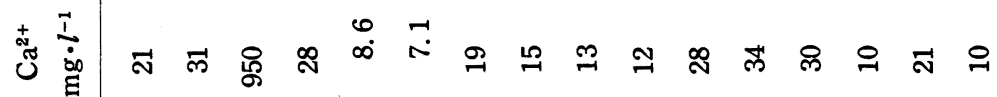

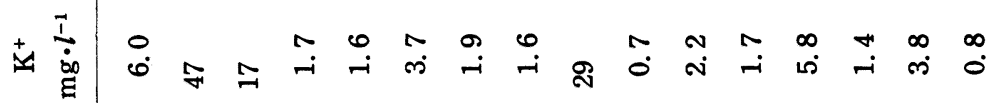

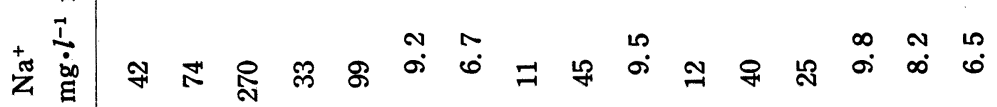

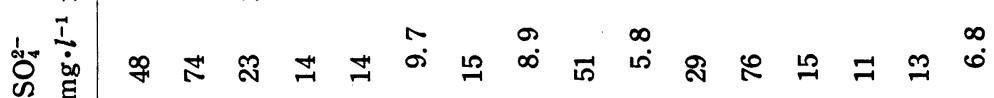

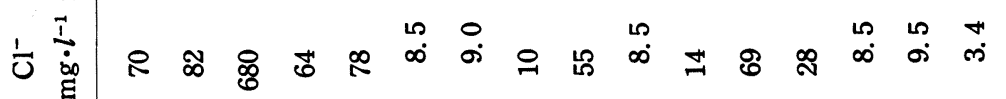
它 $\underset{1}{10}$ 吉 产方

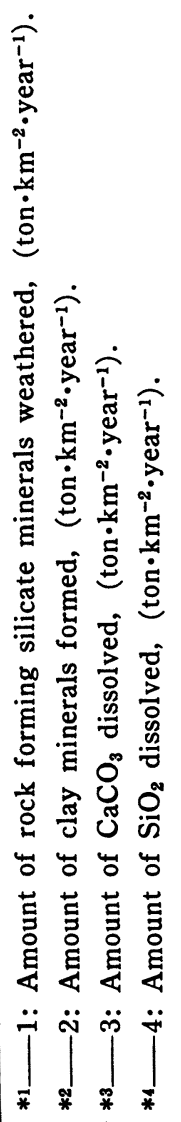


Table 3. Types of the chemical composition of natural waters in the Izu Peninsula area.

\begin{tabular}{l|l}
\hline \multicolumn{1}{c|}{ Region } & \multicolumn{1}{c}{ Type of water quality } \\
\hline Irohzaki & $\mathrm{NaCl}, \mathrm{NaHCO}_{3}$ \\
Yumigahama & $\mathrm{CaCl}{ }_{2}$ \\
Matsuzaki & $(\mathrm{Ca}, \mathrm{Mg})\left(\mathrm{HCO}_{3}\right)_{2}$ \\
Kawazu & $\mathrm{Ca}\left(\mathrm{HCO}_{3}\right)_{2}, \mathrm{MgCl}_{2}, \mathrm{CaSO}_{4}, \mathrm{NaCl}$ \\
Inatori & $\mathrm{CaSO}, \mathrm{CaCl}_{2}, \mathrm{MgCl}_{2}, \mathrm{Na}_{2} \mathrm{SO}_{4}$ \\
Shirata, Naramoto & $\mathrm{Ca}\left(\mathrm{HCO}_{3}\right)_{2}$ \\
Katase & $\mathrm{Ca}\left(\mathrm{HCO}_{3}\right)_{2}, \mathrm{CaCl}_{2}, \mathrm{CaSO}_{4}$ \\
Itoh & $\mathrm{Ca}\left(\mathrm{HCO}_{3}\right)_{2}, \mathrm{NaHCO}_{3}, \mathrm{CaCl}_{2}, \mathrm{CaSO}_{4}$ \\
Sawakuchi & $\left(\mathrm{Ca}, \mathrm{Mg}_{2} \mathrm{HCO}_{3}\right)_{2}$ \\
Nakaizu & $\mathrm{Ca}\left(\mathrm{HCO}_{3}\right)_{2}, \mathrm{CaCl}_{2}, \mathrm{CaSO}_{4}, \mathrm{Na}_{2} \mathrm{SO}_{4}$ \\
Toi & $\mathrm{Ca}\left(\mathrm{HCO}_{3}\right)_{2}$ \\
\hline
\end{tabular}

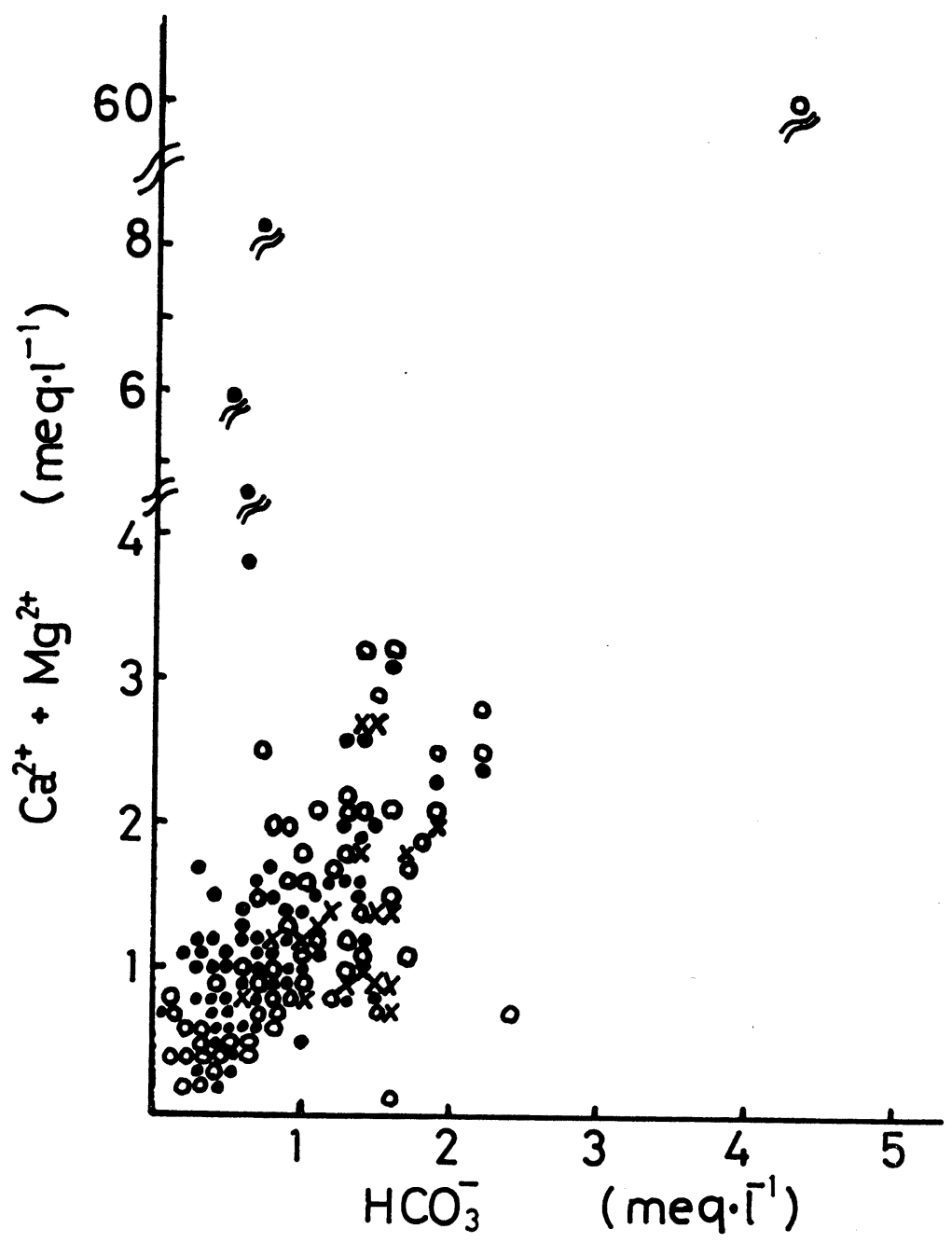

Fig. 2. Relation between $\mathrm{HCO}_{3}^{-}$concentration and $\mathrm{Ca}^{2+}+\mathrm{Mg}^{2+}$ concentration in natural waters.

( $\times, \bigcirc, \bigcirc$ : data in 1976, 1977 and 1978, respectively). 
must be estimated, and the important chemical reactions to dissolve these cations from rocky materials must be identified.

By introducing the estimated amounts of $\mathrm{Na}^{+}, \mathrm{K}^{+}, \mathrm{Ca}^{2+}$ and $\mathrm{Mg}^{2+}$ into the abovenoted important chemical reactions, the equations of the chemical reactions are solved. These detailed procedures were reported previously by KITANO (1980 a, b). The following two processes are expected to occur in the chemical weathering of rocky materials: weathering only by carbonic acid; weathering by both carbonic acid and sulfuric acid.

Sulfuric acid is formed through the oxidation of iron sulfides. When the $\mathrm{SO}_{4}^{2-}$ concentration in ground water is low, the weathering is considered to occur only through carbonic acid; and when it is high, the weathering occurs through both carbonic and sulfuric acids. The chemical weathering of rock forming silicate minerals causes the transformation of silicate minerals into clay minerals (GARRELS and MACKenZie, 1967; Kitano and NAKAMURA, 1973; Kitano, $1980 \mathrm{a}, \mathrm{b}) . \mathrm{HCO}_{3}^{-}$

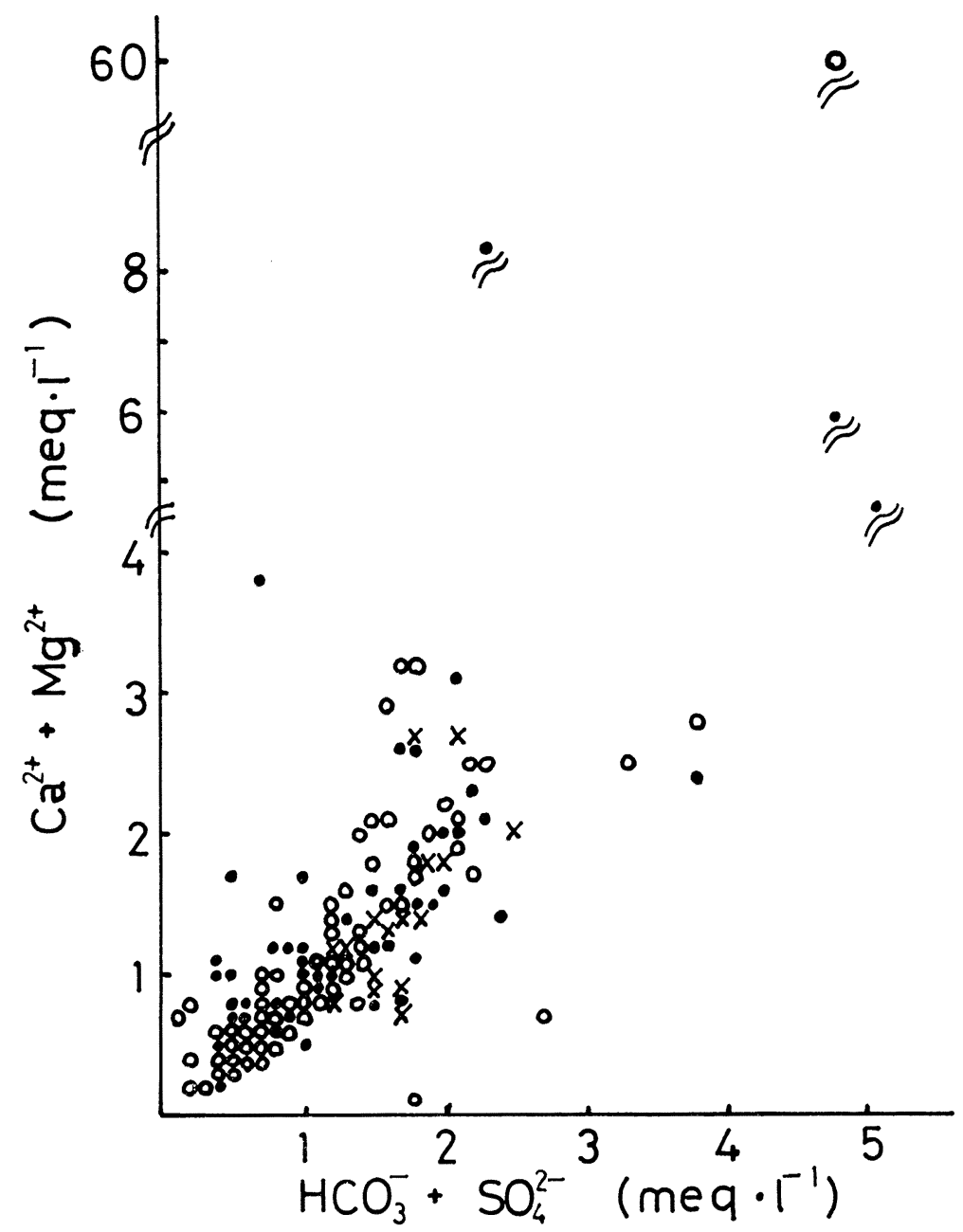

Fig. 3. Relation between $\mathrm{HCO}_{3}^{-}+\mathrm{SO}_{4}^{2-}$ concentration and $\mathrm{Ca}^{2+}+\mathrm{Mg}^{2+}$ concentration in natural waters.

( $\times, \bigcirc$, $\bigcirc$ : data in 1976, 1977 and 1978, respectively). 


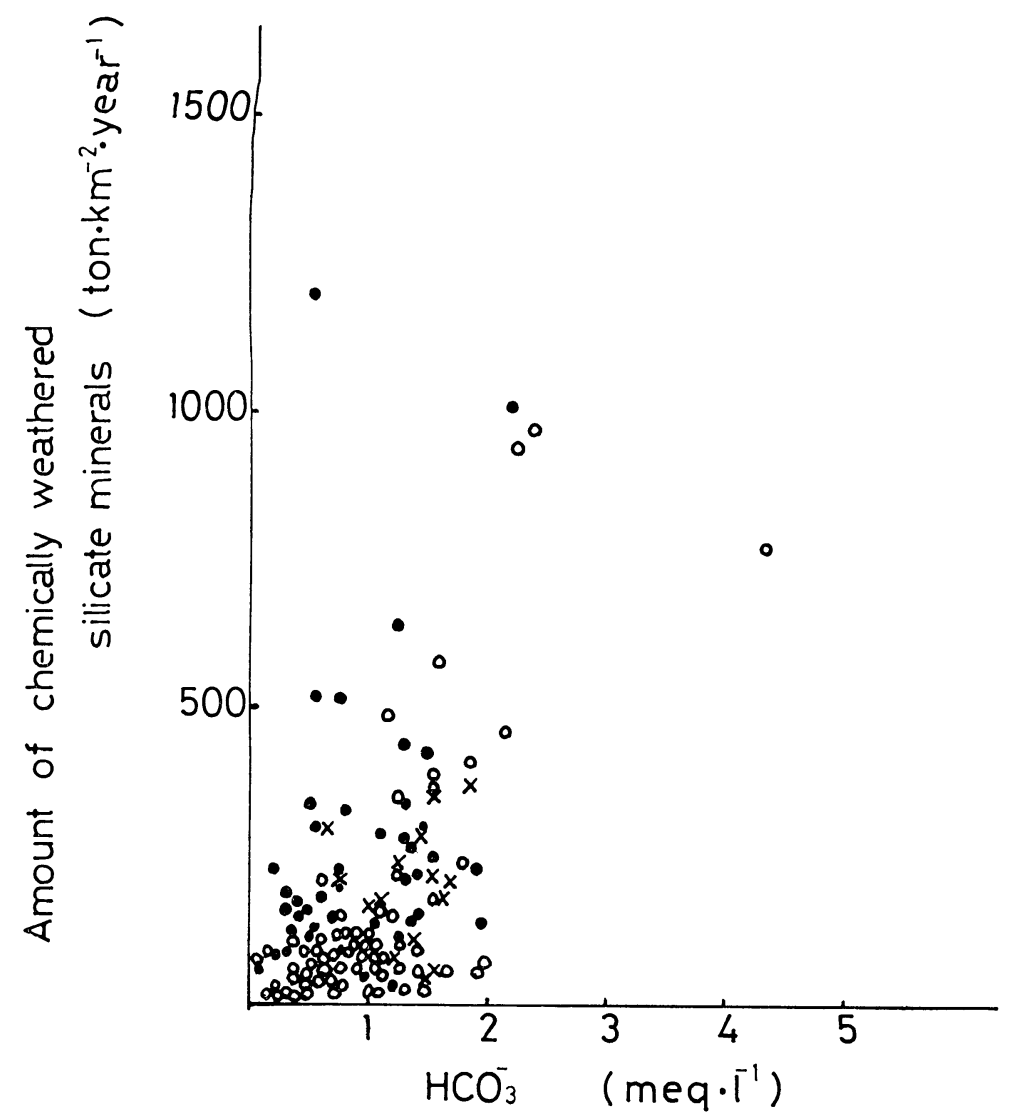

Fig. 4. Relation between $\mathrm{HCO}_{3}^{-}$concentration in the natural waters and amount of chemically weathered silicate minerals.

( $\times, \bigcirc$, data in 1976, 1977 and 1978, respectively).

ions in ground water are supplied through the interaction between carbonic acid and rocky materials, and $\mathrm{SO}_{4}^{2-}$ ions through the interaction between sulfuric acid formed through the oxidation of sulfides and rocky materials. When chemical elements are dissolved from rocky materials through the carbonic and/or sulfuric acid process, calcium and magnesium are dissolved preferentially. This suggests that $\mathrm{HCO}_{3}^{-}$concentration, $\mathrm{HCO}_{3}^{-}+\mathrm{SO}_{4}^{2-}$ concentration and $\mathrm{Ca}^{2+}+\mathrm{Mg}^{2+}$ concentration in natural water indicate the degree of chemical weathering of rocky material and also the degree of ground stability. This was confirmed earlier (Kitano and NaKamura, 1973; Kitano, $1980 \mathrm{~b}$; ISAGAI and ISAGAI, 1981).
The amounts of silicate minerals weathered, clay minerals formed, and carbonate and silica dissolved were estimated by solving the equations, as shown in Tables $\mathrm{A}, \mathrm{B}$ and $\mathrm{C}$ (Appendix).

Figure 2 shows the relationship between the $\mathrm{HCO}_{3}^{-}$concentration and the $\mathrm{Ca}^{2+}+\mathrm{Mg}^{2+}$ concentration in the natural waters of the Izu Peninsula area.

Figure 3 shows the relationship between the $\mathrm{HCO}_{3}^{-}+\mathrm{SO}_{4}^{2-}$ concentration and the $\mathrm{Ca}^{2+}$ $+\mathrm{Mg}^{2+}$ concentration in the natural waters in the same area.

Figure 4 presents the relationship between the $\mathrm{HCO}_{3}^{-}$concentration in the natural waters and the amount of silicate minerals 


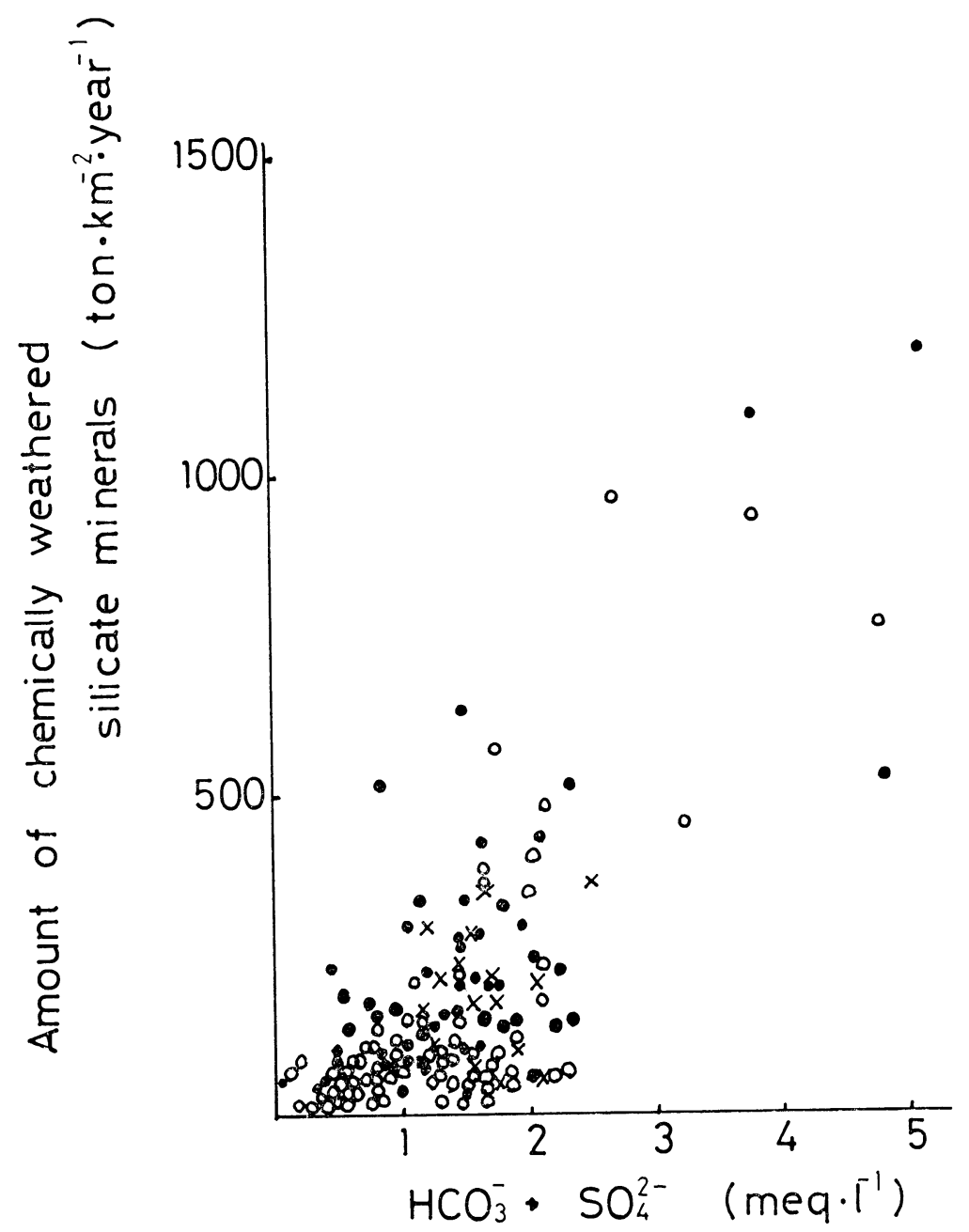

Fig. 5. Relation between $\mathrm{HCO}_{3}^{-}+\mathrm{SO}_{4}^{2-}$ concentration in the natural waters and amount of chemically weathered silicate minerals.

( $\times, \bigcirc$, data in 1976, 1977 and 1978, respectively).

chemically weathered.

Figure 5 gives the relationship between the $\mathrm{HCO}_{3}^{-}+\mathrm{SO}_{4}^{2-}$ concentration in the natural waters and the amount of silicate minerals chemically weathered.

Figure 6 gives the relationship between the $\mathrm{HCO}_{3}^{-}$concentration in the natural waters and the amount of clay minerals formed plus carbonate and silica dissolved.

Figure 7 presents the relationship between the $\mathrm{HCO}_{3}^{-}+\mathrm{SO}_{4}^{2-}$ concentration in the natural waters and the amount of clay minerals formed plus carbonate and silica dissolved.

Figure 8 shows the relationship between the $\mathrm{HCO}_{3}^{-}$concentration in the natural waters and the amount of silicate minerals weathered plus carbonate and silica dissolved.

Figure 9 gives the relationship between the $\mathrm{HCO}_{3}^{-}+\mathrm{SO}_{4}^{2-}$ concentration in the natural waters and the amount of silicate minerals weathered plus carbonate and silica dissolved.

When Figs. 2, 4, 6 and 8 are compared 


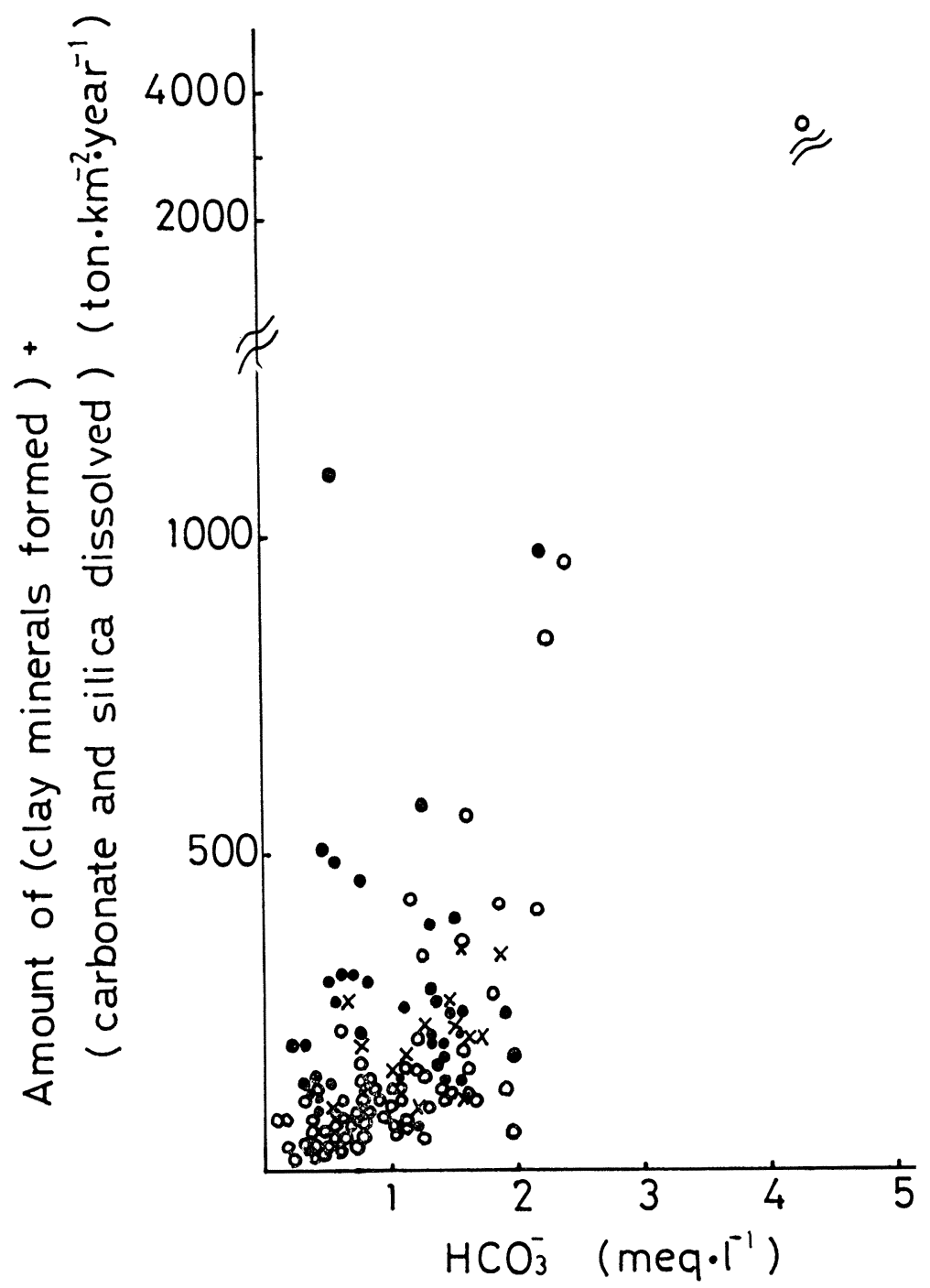

Fig. 6. Relation between $\mathrm{HCO}_{3}^{-}$concentration in the natural waters and amount of (clay minerals formed) + (carbonate and silica dissolved).

( $\times$, , O : data in 1976, 1977 and 1978, respectively).

with Figs. 3, 5, 7 and 9, respectively, the latter figures show a better correlation in values than the former. This may suggest that the chemical weathering of rocks is effected by both carbonic acid and sulfuric acid. It is well known that ground stability decreases with increasing amounts of weathered silicate minerals, formed clay minerals and dissolved carbonate and silica. The formation of clay minerals extremely decreases the ground stability. The dissolution of silica (quartz and amorphous silica) has little influence on the ground stability as compared with the formation of clay minerals, but the carbonate dissolution has a significant role. In practise, the concentration of $\mathrm{HCO}_{3}^{-}$plus $\mathrm{SO}_{4}^{2-}$ in the natural waters in Izu Peninsula may well indicate the degree of ground stability in the area and thereby predicts the size 


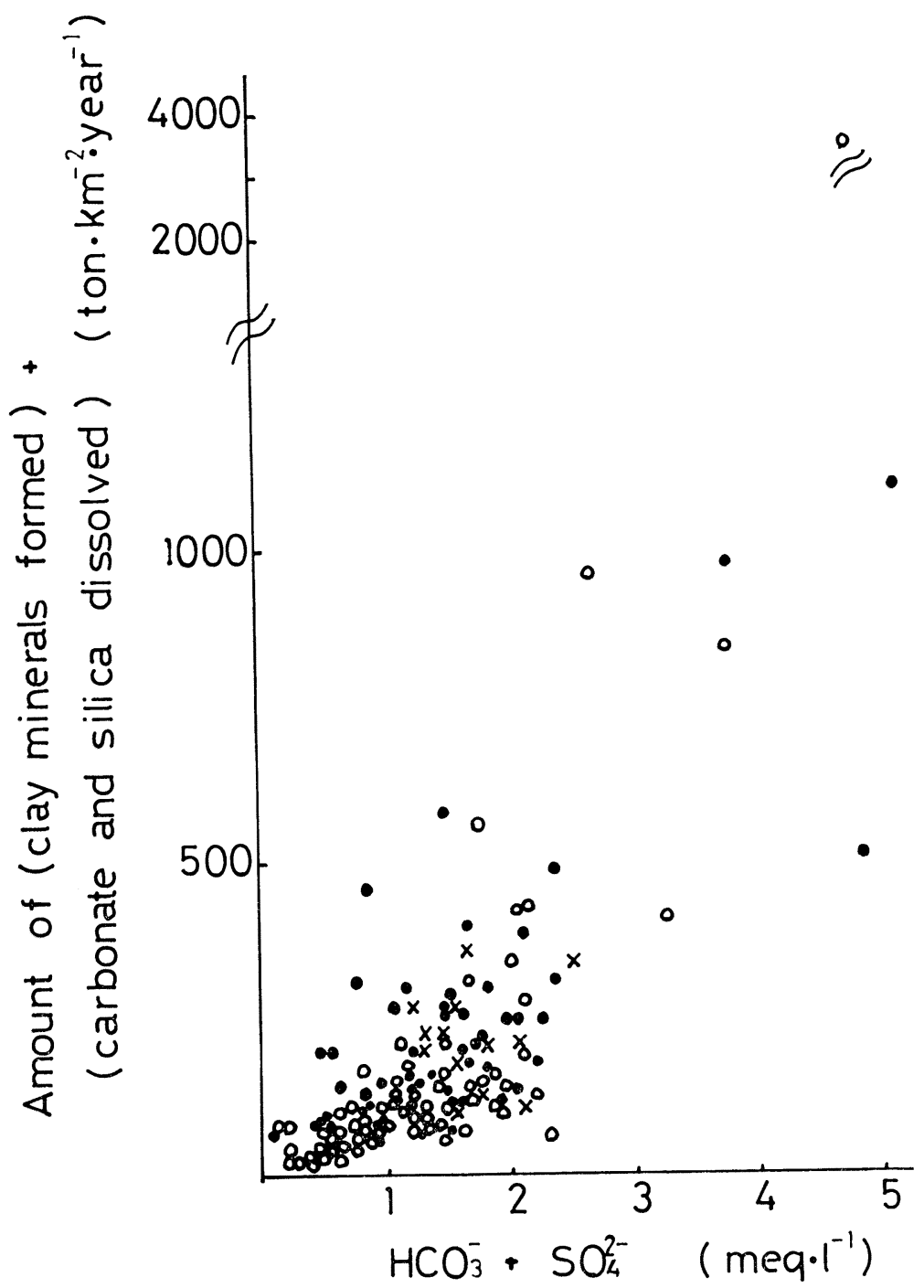

Fig. 7. Relation between $\mathrm{HCO}_{3}^{-}+\mathrm{SO}_{4}^{2-}$ concentration in the natural waters and amount of (clay minerals formed) + (carbonate and silica dissolved).

( $\times, \bigcirc$, : data in 1976, 1977 and 1978, respectively).

and extent of landslides.

Estimation of the amounts of clay minerals formed and rock forming minerals weathered is thus valuable and useful for the prediction and prevention of earthquake disasters.

\section{Acknowledgement}

This study was supported through a grant-inaid from the Ministry of Education, Science and Culture in Japan.
摘要

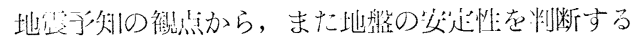
ために仆豆地的の大然水を分析した。

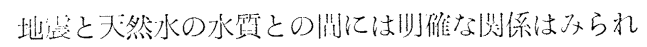

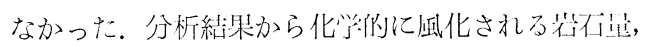

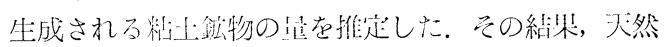

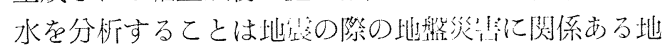
盤の安定性老判断するのに付効であるととがわかった。 


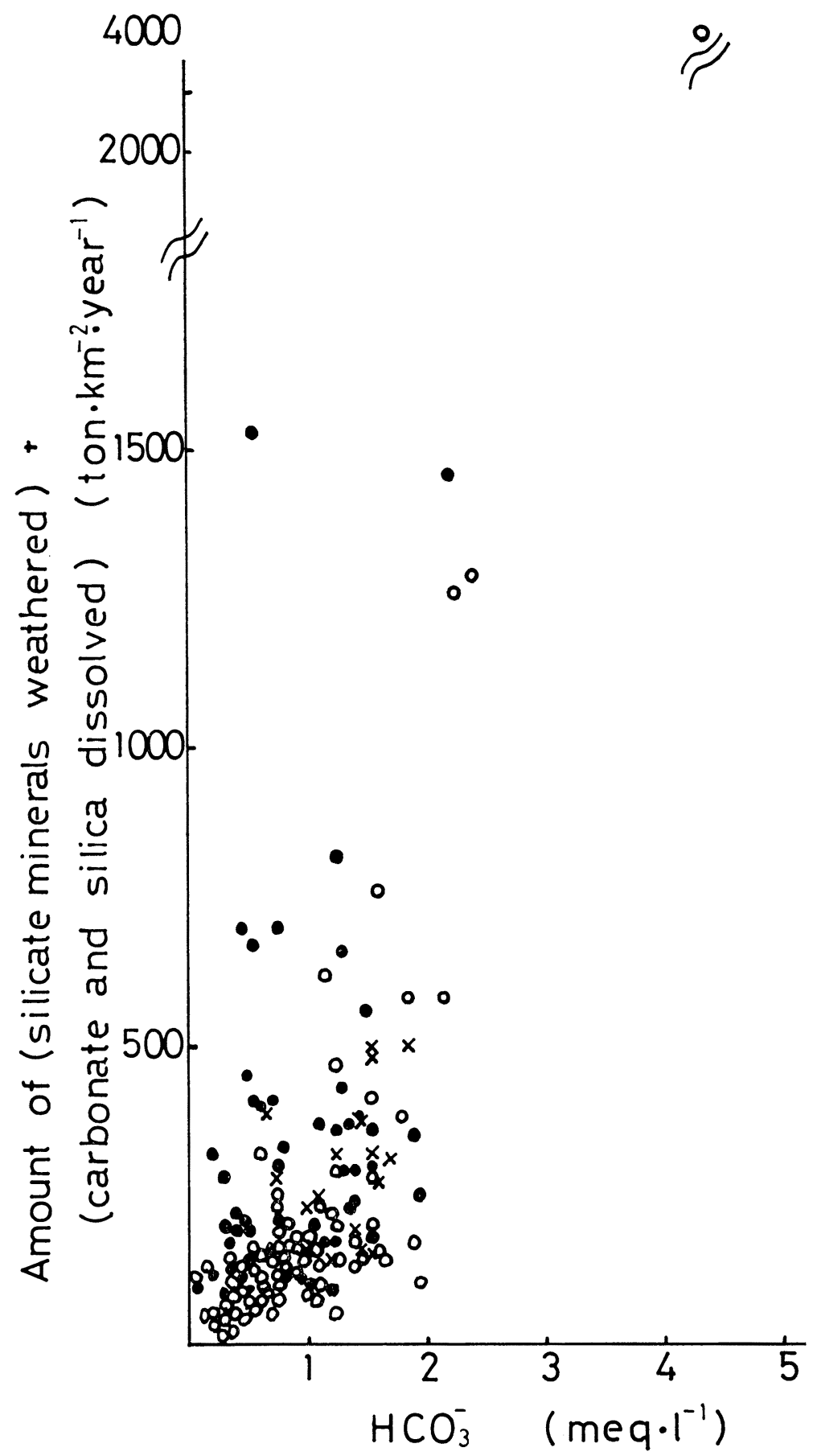

Fig. 8. Relation between $\mathrm{HCO}_{3}^{-}$concentration in the natural waters and amount of ( silicate minerals weathered) + (carbonate and silica dissolved). ( $\times, \bigcirc$, O: data in 1976, 1977 and 1978, respectively). 


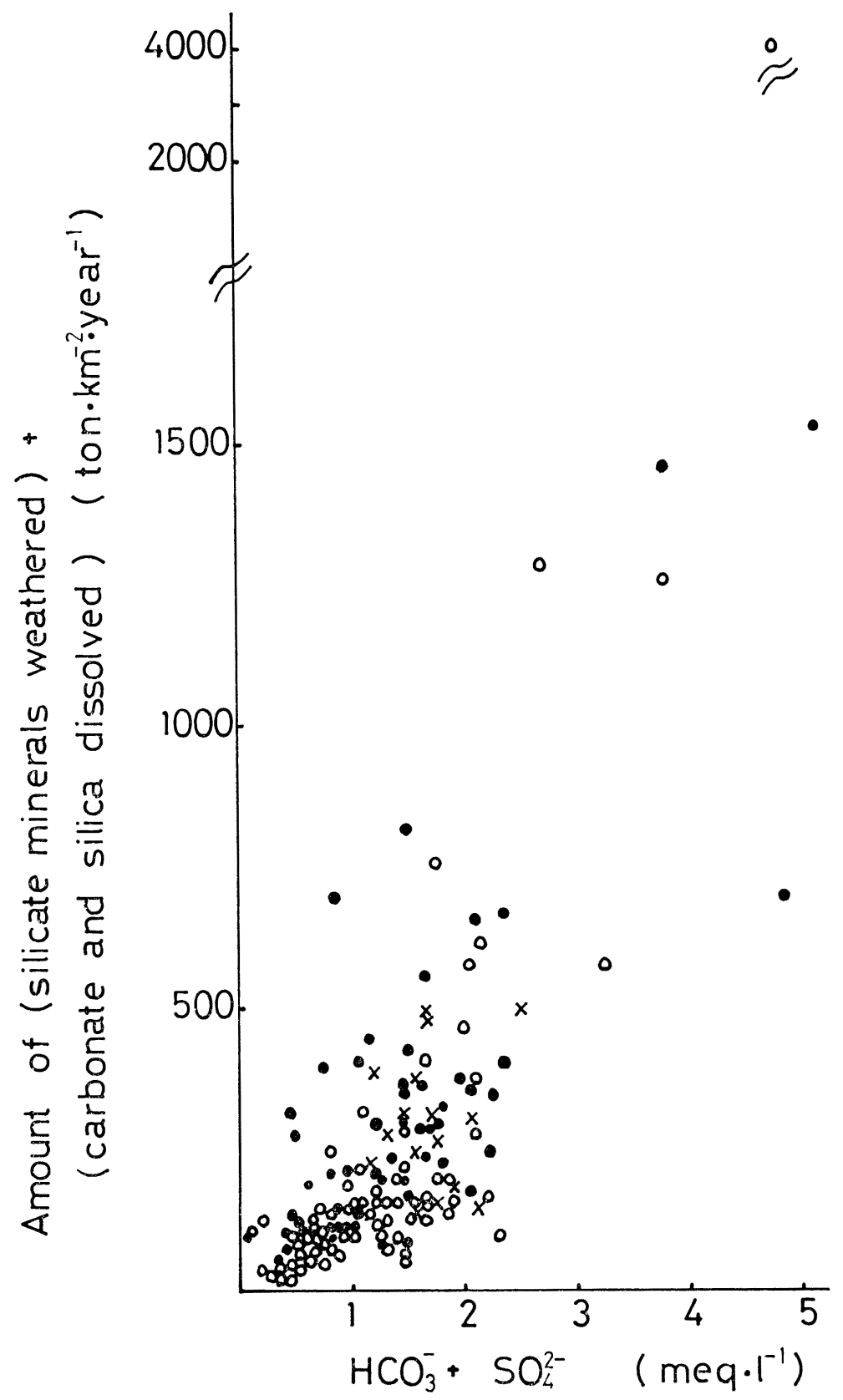

Fig. 9. Relation between $\mathrm{HCO}_{3}^{-}+\mathrm{SO}_{4}^{2-}$ concentration in the natural waters and amount of (silicate minerals weathered) + (carbonate and silica dissolved). ( $\times, \bigcirc$, data in 1976, 1977 and 1978, respectively). 


\section{References}

Garrels, R. M. and F.T. Mackenzie (1967): Origin of the chemical compositions of some springs and lakes. Equilibrium Concepts in Natural Water Systems, Advances in Chemistry Series, 67, Am. Chem. Soc., 222-242.

IsAGAI, K. and K. IsAgAI (1981): Chemical composition of ground water in the Hirayama landslide area in Nagasaki Prefecture. Chikyu Kagaku (Geochemistry), 15: 33-44.

Kitano, Y. (1980 a) : Water-rock interaction and geochemical balance of major chemical elements-With emphasis of geochemical balance of calcium and carbon dioxide. Acta Oceanographica Taiwanica, 11: 40-48.

Kitano, Y. (1980 b) : The formation of clay in land area. p. 63-74. In: Y. Kitano and T. Matsuno (ed.), Chemistry of Earth and Environment (Modern Chemistry 22, pp. 261). Iwanami Co.

Kitano, Y. and S. Nakamura (1973): Landslide and water quality. Sekogijutsu, 6: 17-24.

Kitano, Y., R. Yoshioka and S. Okuda (1968): Geochemical study of ground waters in the Matsushiro area. Part 2. Bull. Disas. Prev. Inst., Kyoto Univ., 18: 49-58.

Kitano, Y., R. Yoshioka, S. Okuda and K. Окиnishi (1967) : Geochemical study of ground waters in the Matsushiro area. Part 1. Bull. Disas. Prev. Res. Inst., Kyoto Univ.,
17: 47-71.

NASU, T. (1969) : Spectrophotometric determination of micro amounts of sulfate using thorium-morin complex. Bunseki Kagaku, 18: 1183-1188.

Wakita, H., Y. Nakamura, I. Kita, N. FujiI and K. Notsu (1980): Hydrogen release: New indicator of fault activity. American Association for the Advancement of Science, 210: $188-190$.

Yoshioka, R. (1978) : On the relation between chloride ions content of Shiota hot spring and earthquake at the Yamasaki fault. Disas. Prev. Res. Inst. Nenpo, Kyoto Univ., 21, B-1: 37-41.

Yoshioka, R., S. Okuda and Y. Kitano (1970): Calcium chloride type water discharged from the Matsushiro area in connection with swarm earthquakes. Geochem. J., 4: 61-74.

(著者: 北野 康, 竹村元志, 斯嵨清隆, 名古屋大

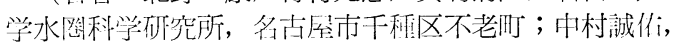

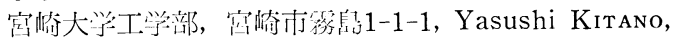
Motoshi Takemura and Kiyotaka Majima, Water Research Institute, Nagoya University, Furo-cho, Chikusa-ku, Nagoya 464 ; Seisuke Nakamura, Faculty of Engineering, Miyazaki University, 1-1-1 Kirishima, Miyazaki 880)

Accepted: 21 January 1983 
Appendix B

Chemical composition of natural waters and amounts of minerals weathered, dissolved and formed in the Izu Peninsula area. Jul. 1977

\begin{tabular}{|c|c|c|c|c|c|c|c|c|c|c|}
\hline $\begin{array}{c}\text { Station } \\
\text { No. }\end{array}$ & $\mathrm{pH}$ & $\begin{array}{l}\mathrm{HCO}_{3}^{-} \\
\mathrm{mg} \cdot \mathrm{l}^{-1} \mathrm{r}\end{array}$ & $\begin{array}{c}\mathrm{Cl}^{-} \\
\mathrm{mg} \cdot \mathrm{l}^{-1}\end{array}$ & $\begin{array}{l}\mathrm{SO}_{4}^{2-} \\
\mathrm{mg} \cdot \mathrm{l}^{-1}\end{array}$ & $\begin{array}{l}\mathrm{Na}^{+} \\
\mathrm{mg} \cdot l^{-1}\end{array}$ & $\begin{array}{c}\mathrm{K}^{+} \\
\mathrm{mg} \cdot l^{-1}\end{array}$ & $\begin{array}{c}\mathrm{Ca}^{2+} \\
\mathrm{mg} \cdot \mathrm{l}^{-1}\end{array}$ & $\begin{array}{c}\mathrm{Mg}^{2+} \\
\mathrm{mg} \cdot \mathrm{l}^{-1}\end{array}$ & $\begin{array}{c}\text { Soluble } \\
\mathrm{SiO}_{2} \\
{\mathrm{mg} \cdot l^{-1}}^{\text {. }}\end{array}$ & $1^{* 1}$ \\
\hline 1 & 6.4 & 77 & 80 & 13 & 39 & 5.8 & 22 & 12 & 50 & 60 \\
\hline 2 & 6.7 & 96 & 95 & 26 & 57 & 11 & 22 & 12 & 51 & 180 \\
\hline 3 & 6.9 & 113 & 62 & 10 & 53 & 9.0 & 26 & 10 & 60 & 410 \\
\hline 4 & 6.7 & 87 & 93 & 10 & 48 & 8.3 & 28 & 8.4 & 68 & 60 \\
\hline 5 & 7.0 & 96 & 110 & 13 & 46 & 4.0 & 40 & 15 & 70 & 60 \\
\hline 6 & 6.8 & 55 & 73 & 20 & 42 & 7.6 & 17 & 9.0 & 41 & 100 \\
\hline 7 & 7.1 & 89 & 134 & 9.3 & 40 & 3.5 & 39 & 12 & 72 & 20 \\
\hline 8 & 7.0 & 88 & 175 & 11 & 38 & 2.4 & 35 & 18 & 72 & 40 \\
\hline 9 & 6.8 & 71 & 28 & 48 & 41 & 3.4 & 21 & 7.9 & 28 & 490 \\
\hline 10 & 6.5 & 62 & 64 & 14 & 33 & 2.3 & 20 & 7.2 & 47 & 20 \\
\hline 11 & 7.3 & 98 & 50 & 3.8 & 31 & 1.4 & 21 & 5.8 & 50 & 70 \\
\hline 12 & 7.3 & 63 & 100 & 21 & 48 & 1.4 & 19 & 10 & 26 & 20 \\
\hline 14 & 7.7 & 74 & 35 & .11 & 26 & 4. 3 . & 12 & 2.8 & 61 & 150 \\
\hline 15 & 6.9 & 64 & 49 & 11 & 29 & 2.0 & 11 & 6.9 & 56 & 60 \\
\hline 16 & 7.1 & 77 & 43 & 8.7 & 36 & 1.2 & 10 & 5.6 & 50 & 220 \\
\hline 17 & 6.4 & 68 & 100 & 15 & 57 & 3.3 & 15 & 6.8 & 83 & 50 \\
\hline 18 & 7.5 & 84 & 43 & 2.0 & 28 & 2.3 & 14 & 4.4 & 63 & 90 \\
\hline 19 & 7.6 & 94 & 33 & 5.7 & 37 & 7.1 & 11 & 1.9 & 60 & 390 \\
\hline 22 & 6.5 & 77 & 89 & 35 & 67 & 4. 4 & 25 & 12 & 46 & 350 \\
\hline 23 & 7.0 & 66 & 67 & 26 & 37 & 5.6 & 17 & 15 & 18 & 80 \\
\hline 24 & 6.7 & 132 & 75 & 53 & 67 & 1.4 & 31 & 12 & 29 & 460 \\
\hline 25 & 6.3 & 54 & 70 & 48 & 42 & 6.0 & 21 & 12 & 37 & 120 \\
\hline 26 & 7.0 & 137 & 82 & 74 & 74 & 47 & 31 & 15 & 32 & 940 \\
\hline 27 & 7.6 & 265 & 680 & 23 & 270 & 17 & 950 & 150 & 26 & 770 \\
\hline 28 & 7.4 & 117 & 64 & 14 & 33 & 1.7 & 28 & 13 & 27 & 60 \\
\hline 29 & 7.6 & 147 & 78 & 14 & 99 & 1.6 & 8.6 & 3.4 & 35 & 970 \\
\hline 30 & 6.5 & 46 & 8.5 & 9.7 & 9.2 & 3.7 & 7.1 & 3.7 & 16 & 120 \\
\hline 31 & 6.2 & 37 & 31 & 24 & 21 & 15 & 8.8 & 4.4 & 20 & 210 \\
\hline 32 & 7.0 & 78 & 64 & 7.5 & 27 & 1.2 & 18 & 3.5 & 47 & \\
\hline 33 & 6.5 & 64 & 27 & 6.9 & 18 & 3. 0 & 11 & 4.7 & 79 & 80 \\
\hline 34 & 9.1 & 99 & 22 & 6.6 & 45 & 1.1 & 0.9 & 0.2 & 79 & 580 \\
\hline 35 & 7.1 & 86 & 57 & 5.0 & 33 & 2.2 & 15 & 7.6 & 49 & 50 \\
\hline 36 & 7.0 & 77 & 61 & 24 & 37 & 4.5 & 20 & 9.2 & 52 & 100 \\
\hline 37 & 6.5 & 66 & 12 & 4.2 & 13 & 3.2 & 12 & 7.4 & 20 & 160 \\
\hline 38 & 6.8 & 42 & 14 & 6.6 & 8.7 & 0.9 & 14 & 10 & 21 & 80 \\
\hline 39 & 6.8 & 21 & 4.3 & 7.9 & 5.1 & 0.5 & 6.2 & 1.4 & 15 & 50 \\
\hline 40 & 7.1 & 41 & 5.8 & 6.4 & 5.3 & 0.5 & 11 & 1.3 & 17 & 40 \\
\hline 41 & 6.9 & 32 & 5.0 & 5.6 & 4.6 & 0.7 & 7.4 & 1.6 & 21 & 40 \\
\hline 42 & 6.5 & 17 & 8.0 & 10 & 6.2 & 0.3 & 8.3 & 2.7 & 14 & 50 \\
\hline 44 & 6.7 & 23 & 5.3 & 5.6 & 4.9 & 0.3 & 5.3 & 1.6 & 17 & 40 \\
\hline 46 & 6.3 & 54 & 9.0 & 15 & 6.7 & 1.9 & 19 & 4.8 & 13 & 60 \\
\hline 48 & 6.5 & 61 & 10 & 8.9 & 11 & 1.6 & 15 & 4.1 & 16 & 120 \\
\hline 49 & 7.0 & 47 & 5.8 & 6.5 & 5.9 & 0.7 & 11 & 2.8 & 23 & 60 \\
\hline 50 & 7.2 & 38 & 3. 0 & 3.4 & 5.6 & 0.8 & 7.3 & 2.2 & 26 & 80 \\
\hline 51 & 6.9 & 30 & 3.8 & 5.6 & 3. 7 & 0.9 & 6.5 & 1.7 & 19 & 40 \\
\hline 52 & 5.8 & 4.6 & 7.3 & 1.8 & 6.6 & 0.7 & 6.3 & 4.3 & 12 & 70 \\
\hline 53 & 6.1 & 8.9 & 9.0 & 1.7 & 8.0 & 2.4 & 7.3 & 5.7 & 8 & 90 \\
\hline 56 & 6.9 & 27 & 5.8 & 1.9 & 5.1 & 0.5 & 2.8 & 2.2 & 22 & 40 \\
\hline 57 & 6.4 & 27 & 10 & 15 & 7.4 & 1.3 & 11 & 4.8 & 17 & 60 \\
\hline$\cdot 62$ & 6.4 & 65 & 9.5 & 24 & 8.6 & 1.0 & 19 & 6.6 & 26 & 100 \\
\hline 97 & 6.6 & 22 & 5.0 & 6.0 & 5.3 & 0.9 & 5.1 & 2.0 & 24 & 60 \\
\hline 99 & 6.9 & 35 & 7.0 & 4.2 & 8.2 & 0.4 & 6.3 & 0.6 & 21 & 90 \\
\hline 100 & 7.1 & 46 & 12 & 20 & 13 & 1.0 & 21 & 5.5 & 21 & 150 \\
\hline 101 & 6.9 & 48 & 14 & 29 & 12 & 2.2 & 28 & 7.0 & 33 & 120 \\
\hline 102 & 6.8 & 43 & 69 & 76 & 40 & 1.7 & 34 & 9.3 & 36 & 70 \\
\hline 103 & 6.9 & 38 & 5.0 & 3.6 & 5.2 & 1.0 & 8.0 & 2.8 & 34 & 60 \\
\hline 104 & 7.1 & 58 & 11 & 8.5 & 9.0 & 1.6 & 15 & 4.5 & 40 & 80 \\
\hline 105 & 7.0 & 45 & 14 & 3.2 & 6.8 & 14 & 17 & 2.2 & 14 & 140 \\
\hline 106 & 6.0 & 12 & 10 & 1.2 & 3.9 & 1.2 & 3.6 & 2.9 & 11 & 20 \\
\hline 107 & 7.1 & 42 & 8.0 & 2.0 & 4.6 & 0.7 & 7.1 & 2.8 & 33 & 20 \\
\hline 108 & 6.2 & 20 & 8.0 & 1.8 & 3.9 & 0.8 & 3.6 & 2.6 & 19 & 20 \\
\hline 109 & 6.7 & 14 & 5.8 & 0.8 & 3.7 & 0.4 & 2.5 & 1.3 & 15 & 20 \\
\hline 110 & 6.0 & 12 & 8.3 & 8.5 & 4.8 & 0.7 & 6.3 & 3.3 & 17 & 30 \\
\hline 111 & 6.1 & 32 & 8.3 & 7.1 & 5.7 & 1.6 & 9.6 & 2.5 & 18 & 40 \\
\hline 112 & 6.7 & 25 & 5.5 & 2.4 & 4.5 & 0.7 & 4.5 & 1.7 & 29 & 40 \\
\hline 113 & 6.6 & 25 & 5.3 & 2.8 & 4.5 & 0.7 & 3.7 & 1.6 & 33 & 40 \\
\hline 114 & 6.8 & 26 & 7.3 & 3.2 & 4.5 & 1.0 & 3.6 & 1.5 & 35 & 20 \\
\hline 115 & 6.3 & 28 & 5.5 & 6.6 & 7.0 & 1.5 & 5.7 & 1.8 & 22 & 90 \\
\hline 116 & 7.4 & 37 & 6.0 & 5.6 & 8.8 & 0.5 & 8.4 & 0.1 & 15 & 110 \\
\hline 117 & 7.1 & 53 & 5.0 & 8.6 & 7.7 & 1.0 & 14 & 0.9 & 21 & 100 \\
\hline 118 & 6.8 & 29 & 5.5 & 8.1 & 5.1 & 0.5 & 7.6 & 1.3 & 18 & 50 \\
\hline 119 & 6.3 & 34 & 9.0 & 5.6 & 7.7 & 3.2 & 6.6 & 2.4 & 22 & 90 \\
\hline 120 & 6.8 & 21 & 7.8 & 1.9 & 3.2 & 0.8 & 3.6 & 1.1 & 24 & 10 \\
\hline 121 & 6.8 & 21 & 5.8 & 0.6 & 2.8 & 1.0 & 3.8 & 1.1 & 25 & 10 \\
\hline 122 & 7.0 & 37 & 4.8 & 2.6 & 4.0 & 0.9 & 6.7 & 2.1 & 28 & 40 \\
\hline 123 & 6.7 & 45 & 19 & 6.0 & 6.0 & 3.0 & 8.8 & 3.8 & 17 & 30 \\
\hline 124 & 6.3 & 20 & 9.5 & 9.9 & 5.2 & 1.1 & 6.1 & 2.8 & 21 & 20 \\
\hline 125 & 6.5 & 45 & 8.3 & 13 & 7.2 & 0.6 & 13 & 3.6 & 22 & 70 \\
\hline 126 & 6.7 & 102 & 26 & 8.4 & 14 & 1.8 & 21 & 8.3 & 29 & 50 \\
\hline 127 & 6.7 & 109 & 28 & 15 & 25 & 5.8 & 30 & 4.4 & 27 & 240 \\
\hline 128 & 6.6 & 46 & 8.5 & 11 & 9.8 & 1.4 & 10 & 3.6 & 19 & 120 \\
\hline 129 & 6.6 & 45 & 9.8 & 16 & 10 & 5.2 & 13 & 5.7 & 23 & 150 \\
\hline 130 & 6.3 & 34 & 6.5 & 8.6 & 5.9 & 1.0 & 11 & 2.9 & 20 & 60 \\
\hline 131 & 6.1 & 17 & 9.8 & 3.6 & 5.2 & 0.8 & 4.6 & 2.2 & 18 & 10 \\
\hline 132 & 6.5 & 56 & 9.5 & 13 & 8.2 & 3.8 & 21 & 4.8 & 22 & 100 \\
\hline 133 & 7.2 & 49 & 3.4 & 6.8 & 6.5 & 0.8 & 10 & 1.7 & 21 & 100 \\
\hline 134 & 6.5 & 33 & 3. 9 & 3. 9 & 4. 5 & 0.8 & 7.8 & 1.9 & 15 & 60 \\
\hline
\end{tabular}


Appendix C

Chemical composition of natural waters and amounts of minerals weathered, dissolved and formed in the Izu Peninsula area. Mar. 1978

\begin{tabular}{|c|c|c|c|c|c|c|c|c|c|c|c|}
\hline $\begin{array}{l}\text { Station } \\
\text { No. }\end{array}$ & $\mathrm{pH}$ & $\mathrm{HCO}_{3}^{-}$ & $\mathrm{Cl}^{-}$ & $\mathrm{SO}_{4}^{2-}$ & $\mathrm{Na}^{+}$ & $\mathrm{K}^{+}$ & $\mathrm{Ca}^{2+}$ & $\mathrm{Mg}^{2+}$ & $\begin{array}{c}\text { Soluble } \\
\mathrm{SiO}_{2}\end{array}$ & $1^{* 1}$ & $2^{* 2}$ \\
\hline & & & & & & & & & & & \\
\hline 1 & 6.5 & 54 & 56 & 17 & 34 & 5.2 & 17 & 6.8 & 40 & 100 & 50 \\
\hline 2 & 6.8 & 94 & 92 & 24 & 60 & 10 & 21 & 11 & 51 & 250 & 140 \\
\hline 3 & 7.0 & 115 & 90 & 18 & 58 & 8.9 & 22 & 12 & 59 & 230 & 130 \\
\hline 4 & 6.8 & 83 & 81 & 21 & 49 & 7.7 & 21 & 10 & 65 & 140 & 80 \\
\hline 5 & 7.2 & 96 & 120 & 23 & 51 & 4.8 & 36 & 16 & 65 & 60 & 20 \\
\hline 6 & 7.3 & 45 & 58 & 23 & 41 & 8.3 & 12 & 6.6 & 38 & 230 & 130 \\
\hline 7 & 7.3 & 87 & 96 & 15 & 44 & 3.7 & 30 & 13 & 71 & 50 & 20 \\
\hline 8 & 7.3 & 88 & 97 & 16 & 45 & 4.1 & 30 & 13 & 71 & 50 & 20 \\
\hline 9 & 7.2 & 77 & 26 & 12 & 49 & 3.0 & 19 & 7.6 & 26 & 640 & 400 \\
\hline 10 & 6.5 & 59 & 60 & 14 & 35 & 2.0 & 17 & 7.0 & 50 & 50 & 30 \\
\hline 11 & 7.7 & 95 & 40 & 8.8 & 33 & 2.2 & 17 & 6.3 & 50 & 210 & 130 \\
\hline 12 & 7.5 & 80 & 69 & 19 & 49 & 2.2 & 18 & 8.7 & 35 & 210 & 130 \\
\hline 14 & 6.5 & 68 & 78 & 24 & 58 & 4.3 & 14 & 6.9 & 78 & 290 & 180 \\
\hline 15 & 7.4 & 64 & 43 & 10 & 31 & 1.5 & 12 & 6.6 & 58 & 140 & 90 \\
\hline 16 & 7.6 & 78 & 41 & 8.6 & 38 & 1.2 & 9.3 & 5.3 & 55 & 280 & 180 \\
\hline 18 & 7.9 & 83 & 33 & 5.4 & 32 & 3.5 & 13 & 4.6 & 61 & 270 & 170 \\
\hline 19 & 8.3 & 92 & 32 & 6.9 & 39 & 7.2 & 12 & 2.2 & 64 & 430 & 270 \\
\hline 22 & 7.0 & 80 & 92 & 37 & 73 & 5.8 & 23 & 11 & 50 & 440 & 270 \\
\hline 23 & 7.6 & 87 & 52 & 26 & 42 & 6.1 & 13 & 12 & 23 & 300 & 170 \\
\hline 25 & 6.5 & 50 & 63 & 48 & 50 & 6.8 & 13 & 10 & 38 & 330 & 200 \\
\hline 26 & 7.1 & 134 & 75 & 76 & 79 & 47 & 26 & 13 & 33 & 1100 & 620 \\
\hline 28 & 7.4 & 118 & 60 & 13 & 38 & 1.4 & 26 & 12 & 30 & 140 & 70 \\
\hline 31 & 6.2 & 35 & 32 & 24 & 25 & 19 & 9.2 & 4.9 & 23 & 300 & 160 \\
\hline 32 & 7.6 & 79 & 25 & 9.9 & 33 & 0.7 & 12 & 3.0 & 49 & 340 & 220 \\
\hline 35 & 7.6 & 85 & 43 & 9.6 & 35 & 2.1 & 12 & 7.2 & 50 & 220 & 130 \\
\hline 36 & 7.5 & 74 & 60 & 13 & 33 & 3.4 & 18 & 8.5 & 54 & 30 & 10 \\
\hline 40 & 7.9 & 42 & 4.8 & 9.0 & 6.8 & 0.2 & 11 & 1.3 & 17 & 80 & 50 \\
\hline 41 & 7.3 & 34 & 4.6 & 5.1 & 6.2 & 0.4 & 7.4 & 1.6 & 23 & 70 & 40 \\
\hline 42 & 7.6 & 41 & 6.1 & 5.1 & 6.6 & 0.1 & 9.2 & 2.0 & 19 & 60 & 40 \\
\hline 43 & 7.1 & 41 & 6.8 & 6.9 & 7.6 & 0.3 & 11 & 2.5 & 23 & 80 & 50 \\
\hline 45 & 6.6 & 50 & 12 & 10 & 10 & 2.2 & 16 & 4.2 & 25 & 90 & 50 \\
\hline 47 & 7.5 & 86 & 8.7 & 12 & 12 & 0.5 & 24 & 4.2 & 26 & 150 & 90 \\
\hline 48 & 6.6 & 62 & 10 & 9.7 & 10 & 1.8 & 14 & 3.7 & 21 & 100 & 60 \\
\hline 49 & 7.8 & 56 & 6.6 & 7.6 & 9.3 & 0.8 & 13 & 2.7 & 26 & 110 & 70 \\
\hline 50 & 7.7 & 38 & 4.4 & 5.4 & 6.3 & 0.5 & 7.9 & 2.5 & 31 & 80 & 50 \\
\hline 51 & 7.4 & 30 & 3.5 & 7.1 & 4.7 & 0.5 & 7.4 & 1.8 & 20 & 60 & 30 \\
\hline 52 & 5.8 & 2 & 9.8 & 1.4 & 7.4 & 0.3 & 6.0 & 4.3 & 9 & 60 & 30 \\
\hline 53 & 6.4 & 13 & 13 & 11 & 12 & 4.0 & 10 & 7.4 & 9 & 230 & 110 \\
\hline 54 & 7.1 & 31 & 7.1 & 34 & 10 & 0.5 & 17 & 2.6 & 16 & 110 & 70 \\
\hline 55 & 6.5 & 28 & 16 & 17 & 13 & 9.0 & 9.1 & 4.5 & 21 & 160 & 80 \\
\hline 56 & 7.5 & 24 & 6.7 & 2.2 & 5.4 & 0.2 & 4.9 & 2.5 & 21 & 40 & 20 \\
\hline 58 & 7.0 & 30 & 7.4 & 12 & 6.4 & 0.9 & 7.9 & 2.7 & 16 & 50 & 30 \\
\hline 59 & 7.2 & 46 & 10 & 16 & 10 & 1.2 & 13 & 3.2 & 19 & 90 & 60 \\
\hline 60 & 7.5 & 38 & 6.7 & 9.1 & 7.8 & 0.4 & 8.3 & 2.7 & 27 & 80 & 50 \\
\hline 61 & 6.5 & 77 & 12 & 11 & 11 & 1.0 & 15 & 6.0 & 39 & 110 & 60 \\
\hline 62 & 6.5 & 70 & 12 & 22 & 11 & 1.0 & 19 & 6.5 & 30 & 110 & 60 \\
\hline 63 & 6.6 & 47 & 55 & 51 & 45 & 29 & 13 & 5.2 & 34 & 520 & 280 \\
\hline 64 & 6.7 & 30 & 38 & 31 & 33 & 14 & 12 & 5.3 & 18 & 340 & 190 \\
\hline 65 & 6.9 & 20 & 18 & 3.6 & 11 & 1.7 & 5.2 & 3.6 & 21 & 40 & 20 \\
\hline 66 & 7.9 & 63 & 8.5 & 5.8 & 9.5 & 0.7 & 12 & 2.6 & 35 & 90 & 60 \\
\hline 67 & 7.4 & 50 & 11 & 5.2 & 9.7 & 0.4 & 10 & 3.6 & 33 & 80 & 50 \\
\hline 68 & 7.9 & 56 & 8.5 & 5.5 & 9.3 & 0.7 & 13 & 2.7 & 35 & 90 & 60 \\
\hline 69 & 7.3 & 28 & 7.9 & 210 & 34 & 0.9 & 110 & 4.7 & 30 & 530 & 340 \\
\hline 70 & 7.7 & 20 & 7.2 & 1.7 & 5.5 & 0.3 & 3.5 & 2.2 & 22 & 40 & 20 \\
\hline 71 & 7.4 & 21 & 16 & 2.9 & 10 & 0.5 & 9.0 & 6.6 & 25 & 60 & 30 \\
\hline 72 & 7.5 & 26 & 18 & 3.0 & 11 & 1.0 & 11 & 5.7 & 28 & 50 & 20 \\
\hline 73 & 7.0 & 17 & 7.8 & 56 & 13 & 0.9 & 17 & 3.0 & 25 & 160 & 100 \\
\hline 74 & 6.3 & 43 & 400 & 78 & 137 & 6.9 & 87 & 48 & 24 & 150 & 50 \\
\hline 75 & 7.5 & 23 & 20 & 19 & 14 & 0.7 & 13 & 7.2 & 21 & 90 & 50 \\
\hline 76 & 6.1 & 22 & 14 & 38 & 14 & 1.7 & 11 & 4.9 & 23 & 130 & 80 \\
\hline 77 & 6.6 & 19 & 12 & 9.4 & 11 & 1.0 & 8.3 & 4.2 & 21 & 90 & 60 \\
\hline 78 & 6.6 & 19 & 16 & 7.3 & 13 & 0.8 & 8.6 & 5.1 & 23 & 100 & 50 \\
\hline 79 & 7.7 & 34 & 19 & 17 & 13 & 0.9 & 13 & 6.8 & 34 & 80 & 40 \\
\hline 80 & 7.2 & 29 & 12 & 7.3 & 9.3 & 0.5 & 8.2 & 3.9 & 30 & 70 & 40 \\
\hline 81 & 6.7 & 35 & 100 & 86 & 84 & 3.9 & 24 & 3.0 & 33 & 520 & 340 \\
\hline 82 & 7.4 & 36 & 10 & 5.6 & 8.3 & 0.5 & 6.7 & 3.3 & 30 & 60 & 40 \\
\hline 83 & 7.7 & 39 & 7.7 & 6.7 & 7.7 & 0.5 & 10 & 3.2 & 30 & 80 & 40 \\
\hline 84 & 7.0 & 34 & 31 & 33 & 19 & 2.7 & 16 & 5.9 & 39 & 60 & 30 \\
\hline 85 & 7.6 & 27 & 10 & 4.6 & 8.3 & 1.3 & 8.5 & 3.9 & 35 & 70 & 40 \\
\hline 86 & 7.6 & 27 & 11 & 4.8 & 8.5 & 1.2 & 7.9 & 4.4 & 31 & 70 & 40 \\
\hline 87 & 7.5 & 27 & 10 & 6.2 & 8.3 & 1.4 & 8.8 & 3.9 & 29 & 70 & 40 \\
\hline 88 & 7.3 & 44 & 11 & 15 & 10 & 1.5 & 13 & 5.3 & 36 & 100 & 50 \\
\hline 89 & 7.3 & 42 & 11 & 14 & 10 & 1.6 & 15 & 5.1 & 36 & 100 & 50 \\
\hline 90 & 6.4 & 17 & 13 & 12 & 16 & 0.5 & 22 & 7.1 & 29 & 190 & 110 \\
\hline 91 & 6.6 & 23 & 14 & 74 & 14 & 0.7 & 18 & 7.7 & 31 & 150 & 80 \\
\hline 92 & 7.4 & 34 & 420 & 220 & 299 & 10 & 78 & 8.7 & 32 & 1200 & 770 \\
\hline 93 & 7.2 & 40 & 12 & 6.5 & 10 & 1.4 & 13 & 4.7 & 35 & 80 & 50 \\
\hline 94 & 7.2 & 47 & 48 & 11 & 25 & 2.8 & 20 & 9.1 & 39 & 40 & 10 \\
\hline 95 & 7.8 & 48 & 15 & 9.0 & 10 & 2.1 & 14 & 6.2 & 39 & 70 & 30 \\
\hline 96 & 7.2 & 27 & 4.4 & 12 & 5.1 & 0.1 & 8.4 & 2.0 & 21 & 60 & 30 \\
\hline 97 & 7.1 & 58 & 5.6 & 2.3 & 6.6 & 0.8 & 5.4 & 2.4 & 37 & 80 & 50 \\
\hline 98 & 7.9 & 41 & 5.6 & 9.5 & 7.8 & 0.6 & 11 & 1.6 & 21 & 100 & 60 \\
\hline 99 & 8.3 & 32 & 4.8 & 4.2 & 9.6 & 0.5 & 6.3 & 0.6 & 24 & 140 & 90 \\
\hline 100 & 7.0 & 45 & 13 & 23 & 14 & 1.7 & 16 & 5.3 & 24 & 160 & 90 \\
\hline 101 & 7.6 & 45 & 12 & 35 & 16 & 2.2 & 22 & 6.1 & 37 & 210 & 130 \\
\hline
\end{tabular}

